\title{
Role of neonatal hyperleptinaemia on serum adiponectin and suppressor of cytokine signalling-3 expression in young rats
}

\author{
Magna Cottini Fonseca Passos ${ }^{1,2}$, Fabiane Pereira Toste ${ }^{1}$, Sheila Cristina Potente Dutra ${ }^{1}$, Paula \\ Affonso Trotta ${ }^{2}$, Fernanda Pereira Toste ${ }^{1}$, Patrícia Cristina Lisboa ${ }^{1}$ and Egberto Gaspar de Moura ${ }^{1}$ \\ ${ }^{1}$ Department of Physiological Sciences, Institute of Biology, State University of Rio de Janeiro, Rio de Janeiro 20550-030, \\ RJ, Brazil \\ ${ }^{2}$ Department of Applied Nutrition, Nutrition Institute, State University of Rio de Janeiro, Av. 28 de Setembro 87, Rio de Janeiro \\ 20550-030, RJ, Brazil
}

(Received 9 January 2008 - Revised 14 April 2008 - Accepted 15 April 2008 - First published online 5 August 2008)

Previously we had shown that neonatal leptin treatment programmes for both hyperleptinaemia and hyperinsulinaemia, which lead to leptin resistance and low expression of the hypothalamic leptin receptor $(\mathrm{OB}-\mathrm{Rb})$ of rats aged $150 \mathrm{~d}$. Here we investigated in young post-weaned rats (age $30 \mathrm{~d}$ ) if leptin treatment during lactation induces leptin and insulin resistance and if those changes are accompanied by changes in the suppressor of cytokine signalling-3 (SOCS-3) expression and serum adiponectin concentration. After delivery, the pups were divided into two groups: (1) a leptin group (Lep) that were injected with leptin daily $(8 \mu \mathrm{g} / 100 \mathrm{~g}$ body weight subcutaneously) for the first $10 \mathrm{~d}$ of lactation; (2) a control (C) group, receiving saline. After weaning (day 21), body weight was monitored until the animals were age $30 \mathrm{~d}$. They were tested for food intake in response to either leptin $(0.5 \mathrm{mg} / \mathrm{kg}$ body weight intraperitoneally) $(\mathrm{CL}, \mathrm{LepL})$ or saline $(\mathrm{CSal}, \mathrm{LepSal})$ when they were aged $30 \mathrm{~d}$. The CL group showed lower food intake, but no response was observed in the LepL group, suggesting leptin resistance. The Lep group had hyperleptinaemia (five-fold), hyperinsulinaemia $(+42.5 \%)$ and lower levels of serum adiponectin $(-43.2 \%)$. The hypothalamic expression of OB-Rb was lower $(-22 \%)$ and SOCS-3 was higher $(+52.8 \%)$ in the Lep group. We conclude that neonatal leptin treatment programmes for leptin resistance as soon as $30 \mathrm{~d}$ and suggests that SOCS-3 appears to be of particular importance in this event. In the Lep group, the lower serum adiponectin levels were accompanied by higher serum insulin, indicating a probable insulin resistance.

Hyperleptinaemia: Adiponectin: Suppressor of cytokine signalling-3: Leptin resistance

Recently, epidemiological and experimental evidence has suggested that intra-uterine undernutrition is closely associated with adulthood obesity related to detrimental metabolic sequelae $\mathrm{e}^{(1-3)}$, giving rise to the concept of 'developmental origins of health and disease ${ }^{,(1,4)}$.

The mother's undernutrition during lactation can programme the higher body weight of their offspring in the adult life ${ }^{(5)}$ and this can be mainly associated with the neonatal leptin surge. Intra-uterine undernutrition is also closely associated with obesity in adulthood. Yura et al. ${ }^{(6)}$ report a mouse model in which undernutrition was applied during gestation; after birth the offspring was fed a high-fat diet and developed higher adiposity. In the neonatal period, undernourished offspring exhibited a premature onset of the neonatal leptin surge compared with offspring with normal intra-uterine nutrition. A premature leptin surge generated in control offspring by exogenous leptin administration led to accelerated weight gain with a high-fat diet. Both undernourished offspring and neonatal leptin-treated control offspring exhibited an impaired response to acute peripheral leptin administration with impaired leptin transport to the brain as well as an increased density of hypothalamic nerve terminals. The present study suggests that the premature leptin surge alters energy regulation by the hypothalamus and contributes to 'developmental origins of health and disease'.

We have shown that leptin treatment in the first $10 \mathrm{~d}$ of lactation programmes for higher food intake and body weight, hyperleptinaemia $^{(7)}$, higher thyroid hormone serum concentration ${ }^{(8)}$, hypothalamic leptin resistance, lower expression of hypothalamic leptin receptor $(\mathrm{OB}-\mathrm{Rb})^{(9)}$ and higher medullar catecholamine content and secretion ${ }^{(10)}$ in adulthood (aged $150 \mathrm{~d}$ ).

Leptin is a cytokine-like peptide that is produced primarily by adipose tissue and inhibits food intake and increases energy expenditure in rodents ${ }^{(11)}$. Leptin and insulin are key hormones involved in the regulation of energy balance and glucose homeostasis. Specific members of the suppressor of cytokine signalling (SOCS) family of proteins are now thought to have a role in the development of leptin and insulin resistance, owing to their ability to inhibit leptin- and insulin-signalling pathways ${ }^{(12)}$.

Abbreviations: C group, control group; Lep group, group injected daily with leptin; NPY, neuropeptide Y; OB-Rb, leptin receptor; SOCS, suppressor of cytokine signalling.

*Corresponding author: Professor Magna Cottini Fonseca Passos, fax +55 21 25876129, email magna.cottini@pq.cnpq.br 
SOCS proteins are induced by a variety of cytokines and act as a negative regulator of cytokine signalling. Among eight SOCS proteins $^{(13,14)}$, leptin specifically induces SOCS-3 mRNA levels at the hypothalamus ${ }^{(15,16)}$ and activates SOCS-3 expression in neuropeptide Y (NPY) and pro-opiomelanocortin neurons ${ }^{(16)}$. Thus, an increase in SOCS-3 mRNA levels could lead to a leptin resistance, by inhibition of the Janus kinase 2-signal transducer and activator of transcription 3 (JAK2-STAT3) pathway or phosphatidylinositol 3-kinase-phosphodiesterase 3B-cyclic AMP (PI3K-PDE3B - cAMP), an alternative pathway of leptin signalling ${ }^{(15,17)}$.

Although the SOCS proteins were initially thought to be primarily involved in the attenuation of cytokine signalling through classical negative feedback, there is now a growing appreciation of a role for SOCS proteins in the negative regulation of receptor tyrosine kinase signalling, such as the inhibition of insulin signalling ${ }^{(18)}$.

Adiponectin acts predominantly in muscle and liver affecting fatty acids and glucose metabolism. Adiponectin has been shown to have insulin-sensitising, anti-atherogenic and anti-inflammatory properties ${ }^{(19)}$. A low serum concentration of adiponectin ${ }^{(20,21)}$ is associated with higher insulinaemia and leptinaemia. Insulin and leptin are proposed to function as adiposity signals in the feedback regulation of food intake $^{(22)}$. Both hormones circulate in the bloodstream in proportion to body fat mass and regulate the activity of neurons found in regions of the brain associated with body-weight regulation ${ }^{(11,23)}$. Development of resistance to the action of these hormones appears to have an important role in the pathogenesis of obesity and type 2 diabetes.

Here, we demonstrate whether neonatal hyperleptinaemia changes serum adiponectin levels and expression of SOCS-3 protein in rats aged $30 \mathrm{~d}$ and if these factors could be associated with the development of leptin and insulin resistance.

\section{Methods}

\section{Animals and treatment}

Animal experimental protocols were approved by the Animal Care and Use Committee of the Biology Institute of the State University of Rio de Janeiro, which based their analysis on the principles described in the Guide for the Care and Use of Laboratory Animals ${ }^{(24)}$. Wistar rats were kept in a room with controlled temperature $\left(25 \pm 1{ }^{\circ} \mathrm{C}\right)$ and with artificial dark-light cycles (lights on from 07.00 to 19.00 hours).

Pups were divided, within $24 \mathrm{~h}$ of birth, into two groups: daily subcutaneously injected with $8 \mu \mathrm{g} / 100 \mathrm{~g}$ body weight $^{(7,9,25)}$ of recombinant mouse leptin (PeproTech Inc., London, UK) (Lep group) for the first $10 \mathrm{~d}$ of lactation and the control group ( $\mathrm{C}$ group) that received instead the same volume of saline $(\mathrm{NaCl} ; 0.9 \%)$. Leptin was dissolved in saline and all the injections were made at 16.00 hours.

Within $24 \mathrm{~h}$ of birth, excess pups were removed, so that only six male pups were kept per dam (six dams), because it has been shown that this procedure maximises lactation performance ${ }^{(26)}$.

At $2 \mathrm{~h}$ after leptin injection, two pups of each litter (Lep and $\mathrm{C}$; six rats) were randomly chosen and blood samples were obtained by decapitation and trunk blood was collected for determination of serum leptin.
The pups were weaned at age $21 \mathrm{~d}$. After weaning, two animals of each litter (six litters of each experimental group) were randomly chosen and placed together in the cage with free access to water and food until they were aged $30 \mathrm{~d}$, when they were killed (twelve animals per group) with a lethal dose of pentobarbital $(0.15 \mathrm{ml} / 100 \mathrm{~g}$ bodyweight, intraperitoneally) and blood was obtained by cardiac puncture.

\section{Body composition analysis}

Body composition (fat and protein mass) was determined at $30 \mathrm{~d}$ by carcass analysis as reported previously ${ }^{(9,27)}$. After killing, the animals were eviscerated, the carcasses were weighed, autoclaved for $1 \mathrm{~h}$ and homogenised in distilled water $(1: 1)$. Samples of the homogenate were stored at $4^{\circ} \mathrm{C}$ before analysis. Then $3 \mathrm{~g}$ of the homogenate were used for determining fat mass gravimetrically. The samples were hydrolysed in a shaking water-bath at $70^{\circ} \mathrm{C}$ for $2 \mathrm{~h}$ with $30 \% \mathrm{KOH}$ and ethanol. The total fatty acids and non-esterified cholesterol were removed with three successive washings with petroleum ether. After drying overnight in a vacuum all tubes were weighed and the results were expressed as $g$ fat $/ 100 \mathrm{~g}$ carcass. Protein mass was determined in $1 \mathrm{~g}$ of homogenate. The tubes were centrifuged at $2000 \mathrm{~g}$ for $10 \mathrm{~min}$. The total protein concentrations were determined by the method of Lowry et al. ${ }^{(28)}$. The results are expressed as $\mathrm{g}$ protein $/ 100 \mathrm{~g}$ carcass.

\section{Adiponectin, insulin and leptin serum quantification}

All assays were performed using RIA kits (Linco Research, Inc., St Charles, MO, USA). The adiponectin kit had a lower detection limit of $0.78 \mathrm{ng} / \mathrm{ml}$ and the inter-assay and intra-assay $\mathrm{CV}$ were 7.31 and $4.09 \%$, respectively. The insulin kit had an assay sensitivity of $0.1 \mathrm{ng} / \mathrm{ml}$ and a range of detection from 0.1 to $10 \mathrm{ng} / \mathrm{ml}$. The inter-assay and intra-assay CV were 4.2 and $8.47 \%$, respectively. The leptin kit measures both rat and mouse leptin with an assay sensitivity of $0.5 \mathrm{ng} / \mathrm{ml}$ and a range of detection from 0.5 to $50 \mathrm{ng} / \mathrm{ml}$. The inter-assay and intra-assay $\mathrm{CV}$ were 6.9 and $7.3 \%$, respectively.

\section{Glucose measurement}

Glycaemia was determined in blood sample from the tail vein of fasting rats using a glucometer (ACCU-CHEK ${ }^{\circledR}$ Advantage; Roche Diagnostics, Mannheim, Germany).

\section{Insulin resistance evaluation}

We evaluated insulin resistance by the product of insulin and glucose:

$$
\text { Insulin resistance index }=\text { fasting insulin }(\mu \mathrm{IU} / \mathrm{ml})
$$

$$
\times \text { fasting glucose }(\mathrm{mmol} / \mathrm{l}) \text {. }
$$

\section{Leptin resistance test}

Peptide. Recombinant mouse leptin (PeproTech, Rocky Hill, NJ, USA) was dissolved in saline vehicle $(0.9 \%$, w/v) and was given as a bolus injection at a dose of $0.5 \mathrm{mg} / \mathrm{kg}$ body weight intraperitoneally. 
Feeding study. At $30 \mathrm{~d}$, the rats of each experimental group (Lep and C) were randomly assigned to one of the following groups: leptin (CL, LepL) or saline (CSal, LepSal) group. The animals were food-deprived for $24 \mathrm{~h}$ while maintaining free access to water before the test. After an intraperitoneal injection of leptin or saline, they were returned to their home cages and provided with a supplementary amount of a standard diet. They were housed singly and food intake was measured by weighing the food cups 2, 4, 6 and $24 \mathrm{~h}$ after leptin or saline injections ${ }^{(5,9,29)}$.

\section{Western blotting analysis}

The hypothalamus, collected under basal conditions, was homogenised in ice-cold lysis buffer (50 mM-HEPES ( $\mathrm{pH}$ 6.4), $1 \mathrm{~mm}-\mathrm{MgCl}_{2}, 10 \mathrm{~mm}$-EDTA, Triton $\mathrm{X}-100$ (1\%), plus aprotinin, leupeptin and soyabean trypsin inhibitor, each one at $1 \mathrm{mg} / \mathrm{ml}$ ). The homogenates were stored at $-20^{\circ} \mathrm{C}$. The protein concentration was determined by the method of Bradford $^{(30)}$.

The proteins $(60 \mu \mathrm{g})$ were separated by SDS-PAGE (12\%) and transferred to a nitrocellulose membrane (Hybond $^{\mathrm{TM}}$ ECL $^{\mathrm{TM}}$; Amersham Pharmacia Biotech, Little Chalfont, Bucks, UK). The membrane was blocked for $30 \mathrm{~min}$ with $2 \%$ bovine serum albumin in Tris-buffered saline Tween 20 (TBS-T) buffer (20 mM-2-amino-2-hydroxymethyl-propane-

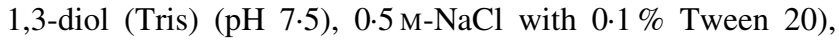
incubated with OB-R-goat polyclonal $\mathrm{IgG}$ primary antibody (1:1000)/SOCS-3-goat polyclonal IgG primary antibody (Santa Cruz Biotechnology, Santa Cruz, CA, USA) in TBS-T overnight, washed three times with TBS-T, and incubated with secondary antibody (peroxidase-conjugated donkey $\operatorname{IgG}, 1: 1000)$, for $1 \mathrm{~h}$. After the membrane was washed three times with TBS-T, the antibody binding was visualised using diaminobenzidine $(5 \mathrm{mg}$ in $10 \mathrm{ml} 0.1 \mathrm{M}$-Tris buffer, pH 7.4). Actin antibody (I-19, SC-1616; Santa Cruz Biotechnology) was used as an internal control. Densitometry analyses of the immunoreactive bands were determined by Image-Pro ${ }^{\circledR}$ Plus software (Media Cybernetics, Inc., Bethesda, MD, USA).

\section{Statistical analysis}

The data are reported as mean values with their standard errors. Two-way ANOVA followed by the Newman-Keuls multiple comparisons test were used to analyse bodyweight evolution and food intake in response to the acute leptin treatment. Other experimental observations were determined by Student's $t$ test with the significance level set at $P<0.05$.

\section{Results}

\section{Body composition}

Body weight from birth until age $30 \mathrm{~d}$ is shown in Fig. 1. During that time, the Lep group had a lower body weight than the $\mathrm{C}$ group, from the third day of leptin injection to the 21 st day (approximately $-5 \% ; P<0.04$ ). After day 21 , these animals regained body weight, and reached the same weight
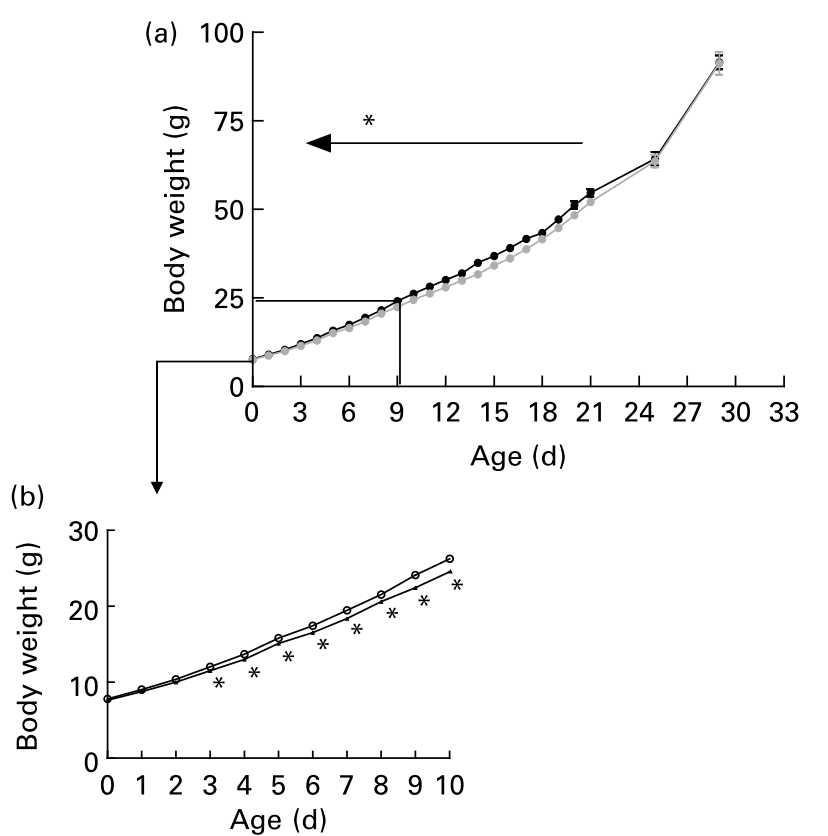

Fig. 1. (a) Body weight from birth until age $30 \mathrm{~d}$ of animals treated with saline (-) ) or with leptin (--) on the first $10 \mathrm{~d}$ of lactation. Values are means of twelve animals per group. $(\leftarrow)$, Significant differences between the treated and control groups from the third day of leptin injection to day $21:{ }^{\star} P<0.05$. (b) Values from day 0 to day 10 for the control $(-O-)$ and leptin-treated $(-\boldsymbol{\Delta}-)$ rats. ${ }^{*}$ Mean value for the leptin-treated group was significantly different from that of the control group $(P<0.05)$.

of the $\mathrm{C}$ group at the end of the experimental period. Despite their normal body-weight gain, their fat mass was lower $(-22.2 \% ; P<0.004)$ and protein mass was higher $(+100 \%$; $P<0.0002)$ compared with controls (Table 1).

Serum leptin, insulin, adiponectin, blood glucose and insulin resistance index

The Lep group had a higher serum leptin $(+136 \% ; P<0 \cdot 05)$ concentration $2 \mathrm{~h}$ after the last leptin injection, which confirmed the hyperleptinaemia. Table 1 shows serum hormone concentrations for offspring aged $30 \mathrm{~d}$. The Lep group had higher serum leptin (5-fold; $P<0.0001$ ), higher glycaemia $(+8 \% ; P<0.05)$ and hyperinsulinaemia $(+43 \% ; P<0.05)$, but lower serum adiponectin $(-43.2 \% ; P<0.05)$ compared with the control group. The Lep group showed a significantly higher $(+65 \% ; P<0.05)$ insulin resistance index, which may indicate insulin resistance (Table 1$)$.

\section{Leptin resistance test}

Fig. 2 shows the leptin resistance test for animals aged $30 \mathrm{~d}$. The effectiveness of the test is demonstrated by the result of the control group, where leptin treatment significantly suppressed food intake at $2 \mathrm{~h}(-26.3 \% ; P<0.05), 4 \mathrm{~h}(-21 \%$; $P<0.02)$ and $6 \mathrm{~h}(-17.6 \% ; P<0.05)$ after leptin injection compared with the group that received saline (Fig. 2 (a)). However, the LepL group did not show a similar decrease, in all periods studied, suggesting a resistance to the anorexigenic effect of leptin (Fig. 2 (b)). 
Table 1. Body composition and serum hormone concentrations of animals at age $30 \mathrm{~d}$ that were given daily injections of leptin for the first $10 \mathrm{~d}$ of lactation and control animals

(Mean values with their standard errors for ten animals per group)

\begin{tabular}{|c|c|c|c|c|}
\hline & \multicolumn{2}{|c|}{ Control } & \multicolumn{2}{|c|}{ Leptin-injected } \\
\hline & Mean & $\mathrm{SE}$ & Mean & SE \\
\hline Body fat ( $\mathrm{g} / 100 \mathrm{~g}$ carcass) & 5.61 & 0.34 & $4.33^{*}$ & 0.21 \\
\hline Body protein ( $\mathrm{g} / 100 \mathrm{~g}$ carcass) & 5.59 & 0.35 & $11 \cdot 23^{*}$ & 0.98 \\
\hline Serum leptin (ng/ml) & 0.79 & 0.12 & $4.79^{*}$ & 0.67 \\
\hline Serum insulin $(\mu \mathrm{lU} / \mathrm{ml})$ & 27.72 & 1.80 & $39 \cdot 51^{*}$ & 4.80 \\
\hline Serum glucose $(\mathrm{mg} / \mathrm{l})$ & 97.40 & 1.79 & $105 \cdot 90^{*}$ & 3.05 \\
\hline Serum adiponectin $(\mu \mathrm{g} / \mathrm{ml})$ & 4.31 & 0.20 & $3.47^{*}$ & 0.05 \\
\hline $\begin{array}{l}\text { Insulin resistance index } \\
(\mu \mathrm{IU} \text { insulin/ml } \\
\times \mathrm{mmol} \text { glucose/l) }\end{array}$ & $147 \cdot 10$ & $7 \cdot 13$ & $232 \cdot 30^{*}$ & 27.84 \\
\hline
\end{tabular}

${ }^{*}$ Mean value was significantly different from that of the control group $(P<0.05)$.

Western blotting of the hypothalamic leptin receptor and suppressor of cytokine signalling-3

Western blotting of total protein lysates from the hypothalamus of rats aged $30 \mathrm{~d}$ is shown in Fig. 3. The level of $\mathrm{OB}-\mathrm{Rb}$ was lower $(-21.6 \% ; P<0.05)$, while SOCS-3
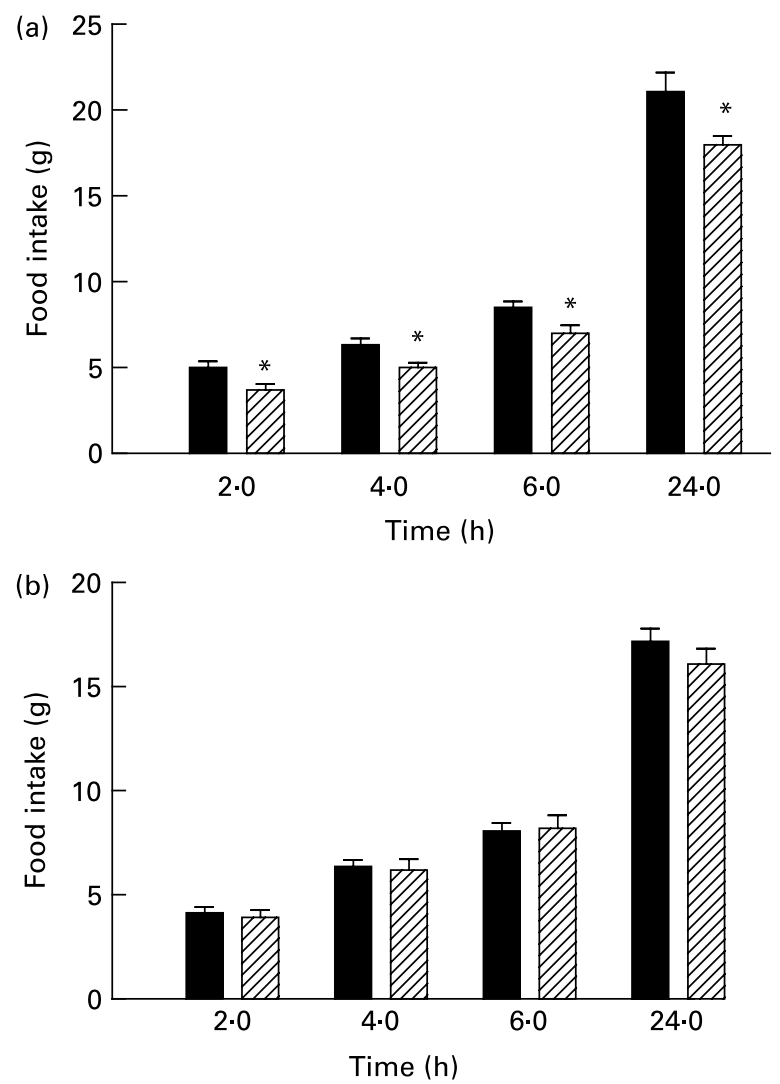

Fig. 2. Effect of acute leptin treatment (國) compared with saline treatment alone ( $\mathbf{\square}$; control) on food intake of rats aged $30 \mathrm{~d}$ that were treated with saline (a) or leptin (b) for the first $10 \mathrm{~d}$ of lactation. Values are the means of cumulative intake for five animals per group, with standard errors represented by vertical bars. * Mean value was significantly different from that of the respective saline control group $(P<0.05)$. (a)
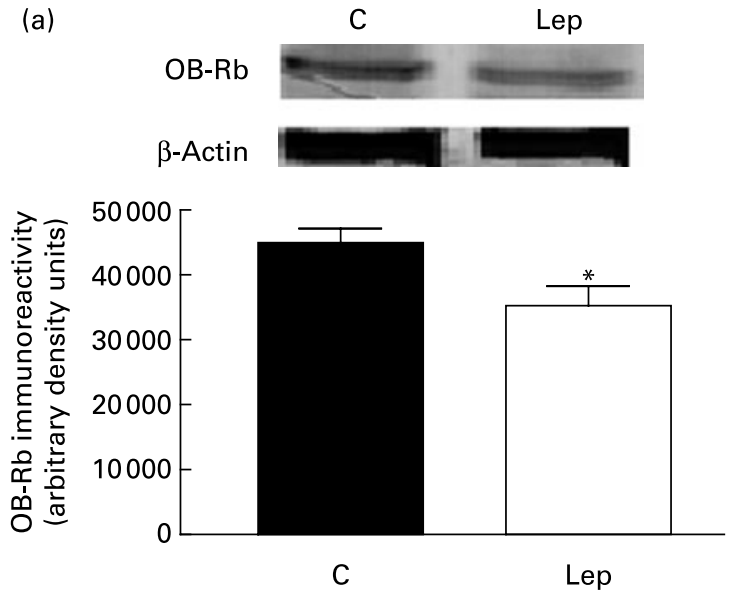

(b)
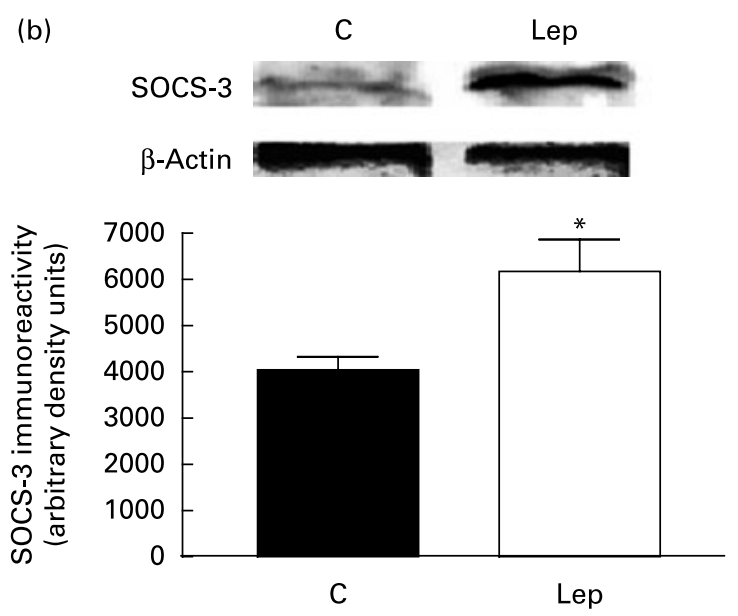

Fig. 3. Western blots of leptin receptor (OB-Rb) (a) and suppressor of cytokine signalling-3 (SOCS-3) (b) in the hypothalamus of rats at age $30 \mathrm{~d}$ that were given daily injections of leptin (Lep) for the first $10 \mathrm{~d}$ of lactation and controls $(C)$ that received the same volume of saline. Shown below the plots are densitometric analyses of the immunoreactive bands for OB-Rb and SOCS-3. A representative experiment is shown from three independent experiments. Data are means of four animals in each group, with standard errors represented by vertical bars. ${ }^{*}$ Mean value was significantly different from that of the control group $(P<0.05)$.

expression was higher $(+52.8 \% ; P<0.002)$ when compared with the control group.

\section{Discussion}

The findings of the present study confirms in young (age $30 \mathrm{~d}$ ) rats similar changes observed in adult ones (age $150 \mathrm{~d}$ ) caused by leptin neonatal programming. At both ages, the rats were programmed for hyperinsulinaemia, hyperleptinaemia and leptin resistance probably due to lower hypothalamic $\mathrm{OB}-\mathrm{Rb}$ expression $^{(9)}$. Here we evaluated other parameters, showing lower adiponectinaemia and higher SOCS-3 expression. The major finding of the present study is that this programming occurs as soon as 1 week after weaning.

In agreement with other studies ${ }^{(31-33)}$ and our previous findings ${ }^{(7-9,34)}$, leptin injected peripherally during the first $10 \mathrm{~d}$ of lactation did increase serum leptin in the neonatal period at age $10 \mathrm{~d}$ and it is still higher at age $30 \mathrm{~d}$. 
Ahima et al. ${ }^{(31)}$ demonstrated in normal lean mice that during the neonatal period leptin rises transiently, which was termed as the 'neonatal leptin surge'. In their experiment, leptin increased 5- to 10-fold to a peak level of 50 (SD 10) ng/ml in mice aged $10 \mathrm{~d}$.

In the neonatal period, leptin alters hypothalamic neuropeptide expression and the metabolic rate before exerting its anorectic effect ${ }^{(32,35)}$. Bouret et al. ${ }^{(36)}$ demonstrated that leptin treatment in ob/ob mice in the neonatal period (4-12 d of life) reverts the reduction in nervous fibres that express pro-opiomelanocortin; the contrary occurred with NPY neurons. However, the treatment during adulthood did not result in the formation of anorexigenic and orexigenic neurons, confirming the existence of a critical period, where the neurons are leptin-dependent for their development in mice.

Several groups reported that exogenous leptin does not significantly inhibit growth, food intake, or energy expenditure during the first $2-3$ postnatal weeks ${ }^{(32,35)}$. More specifically, Mistry et al. ${ }^{(32)}$ have shown that leptin does not alter significantly $\mathrm{O}_{2}$ consumption (a marker of energy expenditure) or food intake in normal lean mice until postnatal day 17. So, this suggests that the neonatal brain is relatively insensitive to leptin and may present leptin resistance ${ }^{(32)}$. However, leptin receptors are expressed in the arcuate nucleus of the hypothalamus (ARH) of rats $^{(37)}$ before the development of ARH pathways.

Leptin also acts as a trophic signal that directs key developmental events in the early hypothalamic pathways that convey leptin signals to brain regions regulating body weight. Events imposed by prenatal nutrition that alter leptin levels may have consequences for the formation and function of circuits that regulate food intake and body weight throughout the life of an animal ${ }^{(36)}$.

Plagemann et al. ${ }^{(38)}$ showed in the small-litter model that the offspring developed overweight, hyperleptinaemia and hyperinsulinaemia, and did not find the expected decrease in NPY content in the arcuate nucleus and paraventricular nucleus when the rats were age $21 \mathrm{~d}$. Since the NPY system is functionally mature already at this age, these findings might indicate an acquired resistance of the hypothalamic NPY system to increased levels of leptin and insulin in early postnatal overfed rats. In another model studied by our group, the prolactin blockage caused a higher transfer of leptin through the milk ${ }^{(39)}$ and the offspring developed higher adiposity and leptin resistance at adulthood ${ }^{(40)}$. Also leptin injection to the mothers during lactation caused similar effects at adulthood ${ }^{(41)}$. Since the rat central nervous system is still developing on the first days postnatally, leptin could imprint the orexigenic and anorexigenic neurons, programming for the development of diseases later in life.

In respect to the programming effects of leptin on bodyweight regulation, our data disagree with some reports ${ }^{(42-44)}$ and agree with others ${ }^{(6,45)}$. In the study of Stocker et al. ${ }^{(42)}$ the administration of leptin from pregnancy and throughout lactation to rats fed on a low-protein diet reduces the susceptibility of a high-fat-diet to induce higher weight gain. However, in that study those authors did not study the effect of maternal leptin treatment in mothers fed a standard chow diet. Our model is a more physiological one, since the animals received a normal diet during all the study.
In the study of Picó et al. ${ }^{(44)}$ a daily oral dose of leptin (5-fold the leptin concentration of milk) was given to suckling male rats during lactation. After weaning the pups were fed with a normal-fat or a high-fat diet. Leptin-treated animals had, in adulthood, lower body weight, fat content, food intake and hypoleptinaemia. These data are similar to our previous study where the lactating rats were submitted to a protein-restricted $\operatorname{diet}^{(46)}$. Offspring with a protein-restricted diet had, in adulthood, lower body weight and this can be mainly associated with a lower milk concentration of protein. It is possible that in the study of Picó et al. ${ }^{(44)}$ that the animals present malnutrition, since oral doses of leptin could lead to an accentuated higher satiety and lower milk intake with consequent protein restriction and lower body weight in adulthood. However, it is also possible, that oral leptin could induce some gastrointestinal mediators that were bypassed by subcutaneous injection.

Vickers et al. ${ }^{(43)}$ showed that leptin injection on the first days of lactation in female rats whose mothers were submitted to energy restriction during pregnancy normalises the bodyweight gain, the food intake and body fat of the offspring in adulthood. However, in this study the neonatal leptin treatment did not cause changes in the female adult offspring from mothers with a normal diet during pregnancy. Moreover, our present findings confirm the recent data of Vickers et al. ${ }^{(45)}$, which showed that the administration of leptin on the first days of lactation in male rats, whose mothers received a normal diet during pregnancy, programmed for higher body weight, hyperinsulinaemia and higher total adiposity. Our findings also corroborate the study of Yura et al. ${ }^{(6)}$ where neonatal leptin-treated rats developed pronounced weight gain, adiposity and leptin resistance later in life.

It is possible that the differences in these studies occur mainly because of the dose, different periods of development (pregnancy and lactation), sex, undernutrition during the treatment and a higher-fat diet after weaning.

In the present study we showed the consequences of neonatal leptin treatment at an early age. The Lep animals presented higher serum leptin and insulin concentrations and, different from observed before in adult animals, the young Lep group had hyperglycaemia and a higher insulin resistance index, suggesting insulin resistance. The development of resistance to the action of these hormones appears to have an important role in the pathogenesis of obesity and type 2 diabetes. The serum adiponectin concentration has been considered an appropriate parameter for evaluation of insulin resistance ${ }^{(47)}$. The Lep group presented, at age 30 and $150 \mathrm{~d}$, lower serum adiponectin; this could be related to their insulin resistance at those ages.

Leptin resistance may occur for one of several reasons: leptin may fail to cross the blood-brain barrier, the hypothalamic receptors may be down-regulated or there may be abnormalities in the leptin receptor signalling pathway, such as SOCS-3 activation ${ }^{(48-50)}$.

We demonstrated that leptin treatment during lactation increases serum leptin concentration in adulthood, which leads to leptin resistance by reducing the expression of the hypothalamic $\mathrm{OB}-\mathrm{Rb}^{(9)}$, since hyperleptinaemia can downregulate its receptors. But here we add another level of complexity to this programming effect, showing the increase in SOCS-3 protein, that can be caused by both hyperleptinaemia 
or hyperinsulinaemia and may be one of the causes of both leptin and insulin resistance.

It is interesting that in this model the first thing to occur is leptin resistance, even with a lower adiposity. Thus, the primary defect seems to be hypothalamic and we suggest that higher SOCS-3 could have an important role blocking the leptin's signalling transduction.

Those animals had hyperleptinaemia even with lower adiposity. Leptin can be produced by other tissues, such as skeletal muscle ${ }^{(51)}$, that is probably higher in those animals that presented higher protein mass. In fact, the hyperleptinaemia in this model seems to be not related to the mass of adipose tissue. Even though in most of the models leptin does correlate with adipose tissue mass, this relationship seems to be not so simple ${ }^{(52)}$; in some cases the relationship is curvilinear, reflecting more the process of fat accumulation than the total fat mass. Since leptin is produced by other tissues, such as muscle ${ }^{(51)}$, the increase of leptin production in those tissues could be the main explanation for these findings. Another explanation could be differences in the leptin clearance of these two groups.

In conclusion, the present results showed that neonatal hyperleptinaemia has a role as a neurotrophic factor that alters energy regulation by the hypothalamus and contributes to developmental programming of leptin and insulin resistance in rats as soon as 1 week after weaning. These effects may be explained by a higher expression of SOCS-3 protein and lower serum adiponectin. Our findings also suggested that the resistance to the anorexigenic effect of leptin at $30 \mathrm{~d}$ can be one of the 'imprinting' factors that associate the hyperleptinaemia during the first $10 \mathrm{~d}$ of lactation with the programming of higher risk to develop diabetes mellitus with ageing.

\section{Acknowledgements}

Research was supported by grants from the National Council for Scientific and Technological Development (Conselho Nacional de Desenvolvimento Científico e Tecnológico; $\mathrm{CNPq}$ ), Coordination for the Enhancement of Higher Education Personnel (Coordenação de Aperfeiçoamento de Pessoal de Nível Superior; CAPES) and the State of Rio de Janeiro Carlos Chagas Filho Research Foundation (Fundação de Amparo à Pesquisa do Rio de Janeiro; FAPERJ). Fernanda P. T. and P. A.T. were recipients of a CNPq fellowship and Fabiane P. T. was a recipient of a CAPES fellowship. All authors are grateful to Ms Monica Gaspar de Moura, Tiago Gomes and $\mathrm{Mr}$ Carlos Roberto for their technical assistance.

M. C. F. P., P. C. L. and E. G. M. designed the study and wrote the protocol and manuscript. Fabiane P. T. managed the literature searches. Fabiane P. T., Fernanda P. T., S. C. P. D. and P. A. T. were responsible for animal programming, and biochemical and molecular procedures. All authors contributed to and approved the final manuscript.

The authors declare no conflict of interest.

\section{References}

1. Breier BH, Vickers MH, Ikenasio BA, Chan KY \& Wong WP (2001) Fetal programming of appetite and obesity. Mol Cell Endocrinol 185, 73-79.
2. Godfrey KM \& Barker DJ (2000) Fetal nutrition and adult disease. Am J Clin Nutr 71, Suppl. 5, 1344S-1352S.

3. Ravelli GP, Stein ZA \& Susser MW (1976) Obesity in young men after famine exposure in utero and early infancy. $N$ Engl J Med 295, 349-353.

4. Gluckman PD \& Hanson MA (2004) Living with the past: evolution, development, and patterns of disease. Science $\mathbf{3 0 5}$, 1733-1736.

5. Passos MCF, Vicente LL, Lisboa PC \& Moura EG (2004) Absence of anorectic effect to acute peripheral leptin treatment in adult animals whose mothers were malnourished during lactation. Horm Metab Res 36, 625-629.

6. Yura S, Itoh H, Sagawa N, Yamamoto H, Masuzaki H, Kawamura M, Takemura M, Kakui K, Ogawa Y \& Fujii S (2005) Role of premature leptin surge in obesity resulting from intrauterine undernutrition. Cell Metab 1, 371-378.

7. Oliveira Cravo C, Teixeira CV, Passos MC, Dutra SC, Moura EG \& Ramos C (2002) Leptin treatment during the neonatal period is associated with higher food intake and adult body weight in rats. Horm Metab Res 34, 400-405.

8. Teixeira CV, Ramos CDF, Mouco T, Passos MCF \& Moura EG (2003) Leptin injection during lactation alters thyroid function in adult rats. Horm Metab Res 35, 367-371.

9. Toste FP, Moura EG, Lisboa PC, Fagundes AT, Oliveira E \& Passos MCF (2006) Neonatal leptin treatment programmes leptin hypothalamic resistance and intermediary metabolic parameters in adult rats. Br J Nutr 95, 830-837.

10. Trevenzoli IH, Valle MM, Machado FB, Garcia RM, Passos MC, Lisboa PC \& Moura EG (2007) Neonatal hyperleptinemia programmes adrenal medullary function in adult rats: effects on cardiovascular parameters. J Physiol 580, 629-637.

11. Schwartz MW, Seeley RJ, Campfield LA, Burn P \& Baskin DG (1996) Identification of targets of leptin action in rat hypothalamus. J Clin Invest 98, 1101-1106.

12. Howard JK \& Flier JS (2006) Attenuation of leptin and insulin signaling by SOCS proteins. Trends Endocrinol Metab 17, $365-371$.

13. Nicholson SE \& Hilton DJ (1998) The SOSC proteins: a new family of negative regulators of signal transduction. J Leukoc Biol 63, 665-668.

14. Krebs DL \& Hilton DJ (2000) SOCS: physiological suppressors of cytokine signaling. J Cell Sci 113, 2813-2819.

15. Bjørbaek C, El-Haschimi K, Frantz JD \& Flier JS (1999) The role of SOCS-3 in leptin signaling and leptin resistance. J Biol Chem 274, 30059-30065.

16. Baskin DG, Hahn TM \& Schwartz MW (1999) Leptin sensitive neurons in the hypothalamus. Horm Metab Res 31, 345-350.

17. Bjørbaek C, Elmquist JK, Frantz JD, Shoelson SE \& Flier JS (1998) Identification of SOCS-3 as a potential mediator of central leptin resistance. Mol Cell 1, 619-625.

18. Pessin JE \& Saltier AR (2000) Signaling pathways in insulin action: molecular targets of insulin resistance. J Clin Invest 106, 165-169.

19. Dyck DJ, Heigenhauser GJ \& Bruce CR (2006) The role of adipokines as regulators of skeletal muscle fatty acid metabolism and insulin sensitivity. Acta Physiol 186, 5-16.

20. Bacha F, Saad R, Gungor N \& Arslanian SA (2004) Adiponectin in youth: relationship to visceral adiposity, insulin sensitivity, and $\beta$-cell function. Diabetes Care 27, 547-552.

21. Cote M, Mauriege P, Bergeron J, Almeras N, Tremblay A, Lemieux I \& Despree JP (2005) Adiponectinemia in visceral obesity: impact on glucose tolerance and plasma lipoprotein and lipid levels in men. J Clin Endocrinol Metab 90, 1434-1439.

22. Schwartz MW, Woods SC, Porte D Jr, Seeley RJ \& Baskin DG (2000) Central nervous system control of food intake. Nature 404, 661-671. 
23. Marks JL, Porte D, Stahl WL \& Baskin DG (1990) Localization of insulin receptor mRNA in rat brain by in situ hybridization. Endocrinology 127, 3234-3236.

24. Bayne K (1996) Revised Guide for the Care and Use of Laboratory Animals available. American Physiological Society. Physiologist 39, 199, 208-211.

25. Malendowicz LK, Macchi C, Nussdorfer GG \& Nowak KW (1998) Acute effects of recombinant murine leptin on rat pituitary-adrenocortical function. Endocr Res 24, 235-246.

26. Fishbeck KL \& Rasmussen KM (1987) Effect of repeated cycles on maternal nutritional status, lactational performance and litter growth in ad libitum-fed and chronically food-restricted rats. J Nutr 117, 1967-1975.

27. Fagundes ATS, Moura EG, Passos MCF, Oliveira E, Toste FP, Bonomo IT, Trevenzoli IH, Garcia RMG \& Lisboa PC (2007) Maternal low-protein diet during lactation programmes body composition and glucose homeostasis in the adult rat offspring. Br J Nutr 98, 922-928.

28. Lowry OH, Rosebrough NJ, Farr AL \& Randall RJ (1951) Protein measurement with the Folin phenol reagent. $J$ Biol Chem 193, 265-275.

29. Martin RL, Perez E, He YJ, Dawson R \& Millard WJ (2000) Leptin resistance is associated with hypothalamic leptin receptor mRNA and protein downregulation. Metabolism 49, 1479-1484.

30. Bradford MM (1976) A rapid and sensitive method for the quantification of microgram quantities of protein utilizing the principle of protein-dye binding. Anal Biochem 72, 248-254.

31. Ahima RS, Prabakaran D \& Flier JS (1998) Postnatal leptin surge regulation and circadian rhythm of leptin by feeding. Implications for energy homeostasis and neuroendocrine function. J Clin Invest 101, 1020-1027.

32. Mistry AM, Swick A \& Romsos DR (1999) Leptin alters metabolic rates before acquisition of its anorectic effect in developing neonatal mice. Am J Physiol 277, R742-R747.

33. Oates M, Noodside B \& Walker CD (2000) Chronic leptin administration in developing rats reduces stress responsiveness partly through changes in maternal behavior. Horm Behav 37, 366-376.

34. Dutra SCP, Moura EG, Rodrigues AL, Lisboa PC, Bonomo I, Toste FP \& Passos MCF (2007) Cold exposure restores the decrease in leptin receptors $(\mathrm{OB}-\mathrm{Rb})$ caused by neonatal leptin treatment in 30-day-old rats. $J$ Endocrinol 195, 351-358.

35. Ahima RS \& Hileman SM (2000) Postnatal regulation of hypothalamic neuropeptide expression by leptin: implications for energy balance and body weight regulation. Regul Pept 92, 1-7.

36. Bouret SG, Draper SJ \& Simerly RB (2004) Trophic action of leptin on hypothalamic neurons that regulate feeding. Science 304, 108-110.

37. Matsuda T, Nakamura T, Nakao K, Arai T, Katsuki M, Heike T \& Yokota T (1999) STAT3 activation is sufficient to maintain an undifferentiated state of mouse embryonic stem cells. EMBO J 18, 4261-4269.

38. Plagemann A, Harder T, Rake A, Waas T, Melchior K, Ziska T, Rohde W \& Dörner G (1999) Observations on the orexigenic hypothalamic neuropeptide $\mathrm{Y}$ system in neonatally overfed weanling rats. $J$ Neuroendocrinol 11, 541-546.

39. Bonomo IT, Lisboa PC, Passos MC, Pazos-Moura CC, Reis AM \& Moura EG (2005) Prolactin inhibition in lactating rats changes leptin transfer through the milk. Horm Metab Res 37, 220-225.

40. Bonomo IT, Lisboa PC, Pereira AR, Passos MC \& de Moura EG (2007) Prolactin inhibition in dams during lactation programs for overweight and leptin resistance in adult offspring. J Endocrinol 192, 339-344.

41. Lins MC, Moura EG, Lisboa PC, Bonomo IT \& Passos MC (2005) Effects of maternal leptin treatment during lactation on the body weight and leptin resistance of adult offspring. Regul Pept 127, 197-202.

42. Stocker CJ, O'Dowd J, Morton NM, Wargent E, Senitt MV, Hislop D, Glund S, Seckl JR, Arch JRS \& Cawthorne MA (2004) Modulation of susceptibility to weight gain and insulin resistance in low birthweight rats by treatment of their mothers with leptin during pregnancy and lactation. Int $J$ Obes 28, 129-136.

43. Vickers MH, Gluckman PD, Coveny AH, Hofman PL, Cutfield WS, Gertler A, Breier BH \& Harris M (2005) Neonatal leptin treatment reverses developmental programming. Endocrinology 146, 4211-4216.

44. Picó C, Oliver P, Sánchez J, Miralles O, Caimari A, Priego T \& Palou A (2007) The intake of physiological doses of leptin during lactation in rats prevents obesity in later life. Int $J$ Obes (Lond) 31, 1199-1209.

45. Vickers MH, Gluckman PD, Coveny AH, Hofman PL, Cutfield WS, Gertler A, Breier BH \& Harris M (2008) The effect of neonatal leptin treatment on postnatal weight gain in male rats is dependent on maternal nutritional status during pregnancy. Endocrinology 149, 1906-1913.

46. Passos MCF, Ramos CF \& Moura EG (2000) Short and long term effects of malnutrition in rats during lactation on the body weight of offspring. Nutr Res 20, 1603-1612.

47. Hara K, Horikoshi M, Yamauchi T, Yago H, Miyazaki O, Ebinuma H, Imai Y, Nagai R \& Kadowaki T (2006) Measurement of the high-molecular weight form of adiponectin in plasma is useful for the prediction of insulin resistance and metabolic syndrome. Diabetes Care 29, 1357-1362.

48. Jéquier $E$ (2002) Leptin signaling, adiposity, and energy balance. Ann N Y Acad Sci 967, 379-388.

49. Friedman JM \& Halaas JL (1998) Leptin and the regulation of body weight in mammals. Nature 395, 763-795.

50. Sahu A (2004) Leptin signaling in the hypothalamus: emphasis on energy homeostasis and leptin resistance. Front Neuroendocrinol 24, 225-253.

51. Wang JL, Liu R, Hawkins M, Barzilai N \& Rossetti L (1998) A nutrient-sensing pathway regulates leptin gene expression in muscle and fat. Nature 393, 684-688.

52. Mantzoros CS \& Moschos SJ (1998) Leptin: in search of role(s) in human physiology and pathophysiology. Clin Endocrinol 49, $551-567$. 